\title{
The Needs of Policy for Photographic Archives' Digitization in Department of Library and Archives of DKI Jakarta Province
}

\author{
Niko Grataridarga ${ }^{1^{*}}$ and Wiwiet Mardiati ${ }^{1}$ \\ ${ }^{1}$ Document and Information Management, Vocational Education Program, Universitas Indonesia \\ *Email:niko.grataridarga@gmail.com
}

\begin{abstract}
This study discusses the needs of photograph archives' digitization at the Department of Library and Archives of DKI Jakarta Province or, in Bahasa, called Dinas Perpustakaan dan Arsip Daerah Jakarta. This is includes understanding what photo archives are, their value, and the need to digitize them. Archives of photographs are important to digitize because they embody information on facts, data, places and people related to the activities of DKI Jakarta government. The photograph archives also have historical value for verification and decision-making for the institution. This research is a qualitative study with observation, interview and literature review. The discussion is further reviewed using perspective theory and standard rules in the implementation of digitizing photo archives. The result is the process of digitizing the archive of photos that have been done but the basics in performing these activities have not been made available yet, so the management of photograph archives has not been maximized and the activities are incidental impressed. Suggestions from this research are the need to have a digitization policy, guidelines and standards about the implementation of digitization of photograph archives.
\end{abstract}

Keywords: digitization, photograph, archives, DKI Jakarta

\section{Introduction}

It is always interesting to discuss the megacity Jakarta, a city in Indonesia that seems to be a reflection and purpose of the progress of the country itself. The long journey of the city of Jakarta, which is almost 500 years old, dates from 1527, and has seen extensive development-not only physical development, but also upheaval that includes culture, economy, population-development relevant to the politics that people are currently talking about. Jakarta, from the Dutch colonial period, was projected to become an ideal city for the colony (Abeyasekere, 1989). The projection in the era of President Soekarno, who formed Jakarta, became a vision to foster national unity and identity for the people of Indonesia. During the three decades of the Orde Baru of President Suharto (1967-1998) governance and the economy were centralized in Jakarta (Rukmana, 2008).

The development and changes that occurred in the long journey of Jakarta are kept in the archives managed by the Library and Archives Department of DKI Jakarta Province (Dinas Perpustakaan dan Kearsipan Provinsi DKI Jakarta). Pearce-Moses (2005) says that archives have information or data that has been fixed on some media and used as an extension of human memory or to demonstrate accountability (Dong, 2015). Therefore, the many Jakarta city archives became evidence of accountability from the city government.

\subsection{Photographic archives and historical reviews}

Many people only understand archives in terms of paper, even though there are other types of archives, such as photos, audio, video, and digital archives. One type of archive stored in Dispusip Jakarta is the photographic archive. Photographs have their own place in record and archive management, whether public or private, or institutional. The photographic archive should be identified, organized or classified, and explained. But archival professionals dealing with these photographs rarely attempt to manage photographic archives, and, more specifically, they have not addressed the question of what role these photographic files are assigned in the actual process of forming the archives (Lacerda, 2011).

The archive can be an actant, that is, a sociological observation of symbolic interactionism. The photographic archive can be a non-human actant record, part of a network of groups, individuals, activities, ideas, and other objects that interact with each other to generate meaning by discourse. This discourse covers more than written or oral communication, it also includes signs and symbols that convey relationships between actors, objects, and other discursive. Examples include movement discourse used between people, types of materials used in buildings (e.g., steel and glass compared to wooden and vinyl boards), to clothing worn (Dong, 2015). Signs and symbols can be a historical study of the meaning of social life using photographic archives. The photographic archive owned by Dispusip Jakarta deserves to be a historical study of an older city, which is older by hundreds of years than the country itself.

As a part of archives, a photographic archive provides archival support for a text archive that records the activities of an organization. Major issues in Jakarta such as development, economy, and culture are reflected in the photographic archive it possesses. Preston et al. (1996) argued that photographs not only deliver corporate 
messages, but also exert the symbolic power to create different types of human subjectivities and realities. From this perspective, it is clear that the role of the photographs is not limited to functionally delivering realities (Ahn and Jacobs, 2018) ${ }^{2}$. Archival photos and paper archives, in the end, will form a complete information construction for evidence of organizational activities.

\subsection{Digitization of the photographic archive}

The historical and evidence values contained in the photographic archive should be the rationale for an institution to start managing photographic archives better. The number of photographs in BPAD acquired from 1969 to 2015 is 108,825 ; that number is enough and requires serious handling. Many of these photographs are celluloid materials that require management with low air temperatures, so need storage capacity, which is not cheap.

Conservation is also required to preserve the image information contained in the archive so that it does not fade. Laminating and de-acidification are examples of the protective conservation examples for the photographic archive. Again, this requires the time, cost, and ability of qualified human resources to do so.

One form of preservation and conservation that can be done well in accordance with the current time is the digitization of archives. Digitizing the archive according to the American Heritage Dictionary (2000) is the activity of converting physical objects to digital in different numerical form in order to be able to computerize (Wentzel, 2006). Furthermore, Wentzel explains that numbers embedded in digital objects can be accessed and manipulated by computer.

Archived photos that have been digitized provide advantages such as providing a surrogate which can be accessed and used instead of the original, thereby assisting in the preservation of the original (Brown, 2006) ${ }^{4}$. In another case, the University of Wyoming collects historic materials in digital archives to make them available to everyone (Person and Plumb, 2017). This is done to make the archives easily accessible, so that the administration and information activities can run quickly and precisely. In addition, Brown (2006) also said a possible advantage from the process is that digitization also allows the enhancement of an image. An archivist's first priority is to maintain the moral and physical integrity of a record. Part of this involves preserving it in its original form, not altering or enhancing it in any way. Even when items are conserved, the work must be obvious and reversible.

\section{Literature Review}

\subsection{Policy}

Pauline Atherton (1978) defines policy as the formulation or general statement of a goal that helps translate these goals from planning to realization, providing administrative guidance for making decisions and their implementation (Vignau, 2005, p.13). According to Lawell, policy is a program that is subjected to specific goals, values, and practices. The detail of policy is often associated with the government, because it is the government that has the authority or power to direct the community, and be responsible for serving the public interest (Naihasy, 2006, p.18).

From the definitions outlined above the authors conclude that:

a. Policies are the realization of the objectives of planning to their implementation, in the form of administrative guidelines for making decisions and their implementation.

b. The policy rule is a concrete picture of planning.

c. Programs in the policy already include the objectives, values, and how the program is implemented.

\subsection{Photographic Archive}

Archive photos are part of the audio-visual archive, which is the archive of information in the form of still images (still visuals). Archive photos are archives born from the photography of either a negative film, digital photos, or positive images or prints thought worth saving (Rusidi, 2009, p.1)

The photographic archive is visual material, or more specifically, the technical images resulting from visual production, including therein photographs and film records. The hegemony of the factual value of images is what determines their treatment, and irrespective of the type of archive in question, all effort to identify and describe the material is focused on the facts, people, places, and eras portrayed (Lacerda, 2011) ${ }^{9}$.

\subsection{Digitization Process}

A workflow of the digitization process can be used as policy and guidance reference. Butterworth, Pearson, Sutherland, \& Farquhar (2018) said that workflow for a digitization project considers the entire process, from setting up, through to digitization, to file export, backing up and final deposit of a digital archive. 
This workflow should be considered a guide rather than a prescriptive order, since every project will be slightly different from the next. The workflow can be divided into a five-stage process:

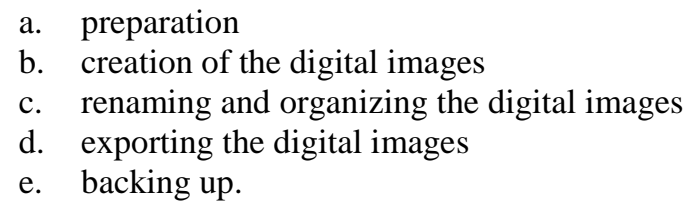

Some government institutions of archival management in the world have their own policies for the process of digitizing their photographic archives. For example, the Yukon Archive which is part of the Department of Tourism and Culture of Canada, Yukon Government, have a Standard for Digitizing Photographs: Creation of Raster Image Masters (2015). This standard cover capture devices, monitors, bit depth, file format, spatial dimensions, scan resolution, and file dimensions. Also, image processing, standard and descriptive metadata, file naming, quality assurance, and storage are all itemized in the standard.

\section{Method}

This research used a qualitative approach to the inquiry, which ensures that the collection of data is in a natural setting, sensitive to the people and places under study, and involves data analysis that is inductive and establishes patterns or themes. These are all good reasons to explore a problem rather than to use predetermined information from the literature or rely on results from other research studies (Creswell, 2007). This approach develops a case study where the object of the research is the activities of digitizing of photograph archive and the research subjects are the archives involved in digitization activities.

Data collection in this research is by observation and interview. The primary data collected comes from observations of archival digitization activities and interviews with archivists involved in that activity. The collected secondary data is derived from the existing literature review. Processing the results of data collection is carried out by comparing the results of interviews and observations as well as the observation document results of digitization activities, with theories and reviews of existing literature.

\section{Results and Discussion}

\subsection{Photographic Archive in Dispusip Jakarta}

The photographic archive of Dispusip Jakarta is on the first floor in a special room for photograph archives. The photographs are stored in envelopes where one envelope could contain one photo but there are also many photos. As can be seen in Figure 1, the envelopes containing the archive photographs are stored in the the filing cabinet.

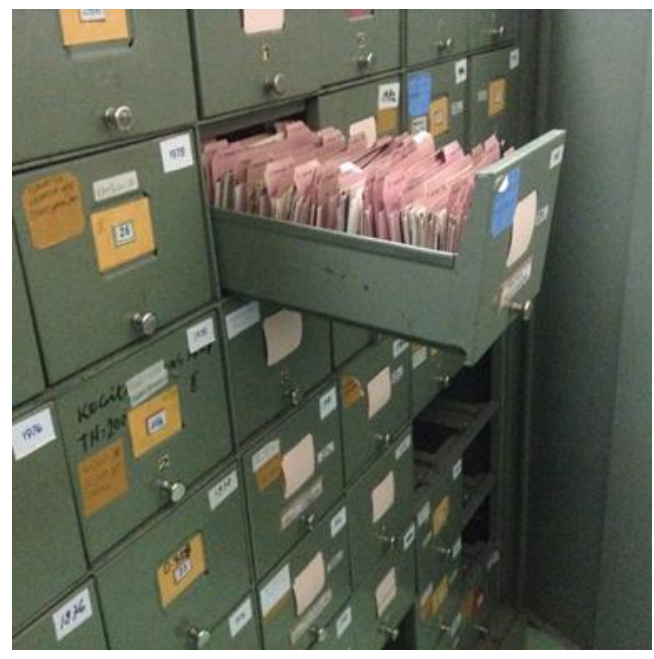

Figure 1. Photograph archive in filing cabinet

Some archive photographs stored in Dispusip are mostly photographs related to the activities of the governor of Jakarta such as the inauguration ceremony, meetings, and the governor's visit to the settlement. There are also photographs of old Jakarta, the phenomena of DKI Jakarta (fire, flood, demo, etc.), the 
development of the city of Jakarta, and the old buildings or historical places in Jakarta that are preserved as cultural heritage sites.

\subsection{Digitization Project of the Photographic Archive}

Digitization activity in Dispusip was last done in 2015. There are four archivists in charge of conserving archives. The digitization process of photographs that Dispusip have carried out entailed rephotographing using a DSLR camera. In Figure 2 an archivist can be seen doing a rephotograph using a DSLR camera and other assistive devices. The DSLR camera equipment is used for the digitization process because Dispusip does not have a special scanner to digitize the photograph archive. Existing scanners are used for digitizing paper archives. In addition, DSLR cameras are considered simpler to use and not directly in contact with the photograph.

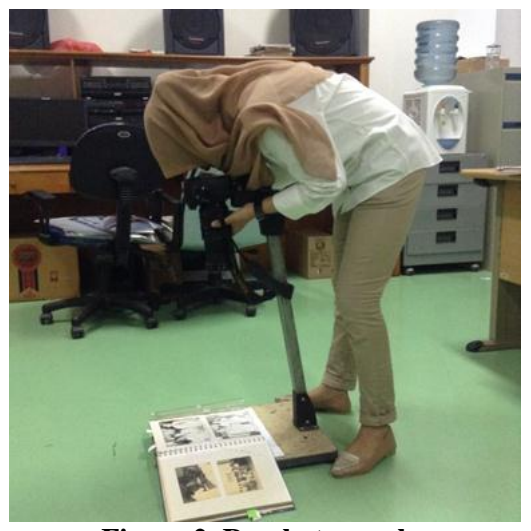

Figure 2. Re-photography

The use of DSLR cameras does have its own advantages as expressed by Greve (2006). In 1997 the University iof Bergen agreed to finance equipment and a photographer, for a two-year project of digital rephotography to take care of these most difficult objects, and at the same time develop a standard for future digital rephotographing. It took a long time to decide on the best equipment for that activity. The first consideration was to choose between a scanner and a camera with a digital back. We decided on a camera for several reasons. With a camera, the size of the object to be digitized presents no problem. Also, we were afraid that the strength and quality of the light emitted by scanners would be harmful to the old photographs, and we did not want to put glass negatives inside a scanner, fearing they would break.

The re-photography process is done in stages, i.e., the archive copy of the photo in the envelope or album is removed first, then placed in the right position for shooting using the SLR camera. The image is then stored in the camera card reader and then transferred into the computer and processed, edited or cropped to be neat and then stored on CD, external hard disk, or computer server. There are several pieces of CD that are the result of digitization from the printed form to the recording form which contains the photograph archives from 1969 to 1971. For the digitization activities of other year-old photo is stored on a hard drive/flash drive.

The results of digitizing the photographic archive other than those stored on electronic media such as CD or hard drive are also published online. This publication is achieved by uploading a digital photograph archive into the Dispusip website so the archive can be accessed more easily and quickly. There is also an offline publication where the results of digitized photo archives are published into a collection of Jakarta archives.

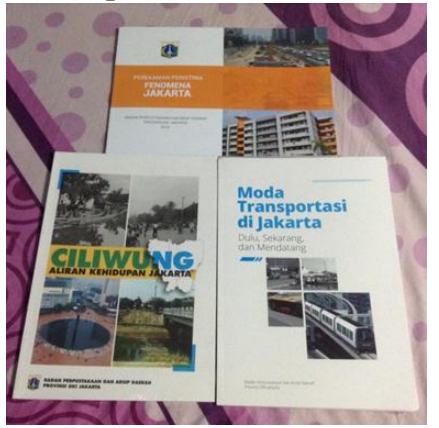

Figure 3. Photographic archives book

The results of digitization activities are usually done to support the exhibition activities at both provincial and national level. The books in Figure 3 are collections of Jakarta's photograph archive for exhibition display. 


\subsection{Policy and the Lack of Digitization Process}

The process of digitizing the photographic archive in Dispusip has several constraints. First, this activity does not have a policy as the basis for its implementation. According to archivists at Dispusip Jakarta, currently the activity of digitization is focused on text archives. The process of digitizing the photograph archive is done in spare time only if the number of text paper archives is not too much to digitize. The photograph archive has not been considered important so there is no definite target planning either in terms of number or assessment of the archive information category. The assessment of the category of information here means the judgment to determine which archives will be digitized could vary with the archive year and be subject to archival issues.

Second, the absence of a policy resulted in the absence of operational procedures as guidelines for the activities of digitizing photograph archives. The digitization process is done by the re-photography method only to produce a digital form that can be stored on other computer media. There are no written steps to performing the activity and there is no quality control guideline on the resolution of digitized results. Dietrich and Adelstein $(2015)^{6}$ said that the archivist needs to ensure that digital material, including the digitized photograph archives, has integrity. Ensuring the integrity of digital materials means that archivists must have the appropriate tools and policies to prove that digital material has not been corrupted or inadvertently altered, either through decay or transfer to other storage environments or repositories.

Third, another constraint is the absence of the appointment and training of archivists who specialize in the field of digitization, not only on digitized paper text archives, but also especially photograph archives. There is a need for a team that plans and conducts this digitization activity. The team of professionals will concentrate on the digitization activities so that the implementation of digitized photograph archives will continue to run and be optimized.

\section{Conclusion}

The activity of digitizing the photograph archive has been done by Dispusip Jakarta but this activity is done in 2015. Until now it has not been re-started for various reasons, such as the archivist being busy with other activities, lack of human resources, and no policies or regulations underlying the activities of digitization. The photographic archive has a very important use for the organization because it has value in verification of Jakarta government activities. In addition, photographic archives are important for service activities in the community for research and study, because it has historical value.

A suggestion addressed to Dispusip Jakarta is to immediately establish a policy on the digitization process. These policies include the planning of activities, the determination of equipment, the flow of execution, and the evaluation of activities. This policy will be a part of a process to achieve the vision of Dispusip which is to realize excellent service in the field of libraries and archives. In addition, it is also in line with the mission of Dispusip to realize the good governance of libraries and archives by applying the rules of good governance and develop facilities and infrastructure of the library and archive nationally and internationally. Therefore, the policies and guidelines on every archival activity and project will maintain the integrity of the institution in achieving its vision and mission.

\section{References}

Abeyasekere, S. (1989). Jakarta: A History. Journal of Southeast Asian Studies, 20(1), 120-122, Published by: Cambridge University Press on behalf of Department of History, National University of Singapore.

Ahn, P., \& Jacobs, K. (2018). Using photographs in interpreting cultural and symbolic meaning: A reflection on photographs of the Korean Association for Government Accounting. Accounting Forum, 42, 142-152. Retrieved from https:// www.elsevier.com/locate/accfor.

Butterworth, J., Pearson, A., Sutherland P., \& Farquhar, A. (2018). Remote capture: Digitising documentary heritage in challenging locations. Open Book Publishers. Retrieved from https:// www.elsevier.com/locate/accfor.

Brown, C. (2006). Digitisation projects at the University of Dundee Archive Services. 40(2), 168-177. doi: $10.1108 / 00330330610669280$.

Creswell, J. W. (2007). Qualitative inquiry and research design: Choosing among five approaches (2nd ed.), California: Sage.

Dietrich, D., \& Adelstein, F. (2015). Archival science, digital forensics, and new media art. Digital Investigation, 14, S137S145. Retrieved from https://www.elsevier.com/locate/diin.

Dong, L. (2015). Taking the long view of medical records preservation and archives. Journal of Documentation, 71(2), 387 400. doi: 10.1108/JD-11-2013-0141

Greve, S. (2006). Digitisation as a strategy for preservation and dissemination of photographic archives, Alvheim \& Eide. Available from http://hdl.handle.net/1956/1831. 
Lacerda, A. (2011). Photographs in archives: The production and meaning of visual records. História, Ciências, SaúdeManguinhos. Retrieved from http://www.scielo.br.

Naihasy, S. (2006). Kebijakan publik (public policy) menggapai masyarakat madani. Yogyakarta: Midi Pustaka

Person, D. A., \& Plumb, T. K. (2017). Digital archives from the ground up. Digital Library Perspectives, 33(3), 253-263. Retrieved from doi: 10.1108/DLP-07-2016-0019

Rukmana, D. (2008). Planning the megacity: Jakarta in the twentieth century. Journal of the American Planning Association, 74(2), 263-264.

Rusidi. (2009). Pengolahan Arsip Foto.

Wentzel, L. (2006). Scanning for digitization projects. Library Hi Tech News, 23( 4), 11-13. doi: $\underline{10.1108 / 07419050610674712}$

Vignau, B., \& Meneses, G. (2005). Collection development policies in university libraries: A space for reflection. Cuba: Collection Building. Diakses pada 21 April 2015 ProQuest.

Yukon Goverment. (2015). Yukon Archives Standard for digitizing photographs: Creation of raster image masters. Retrieved from http://www.tc.gov.yk.ca/pdf/Yukon_Archives_Photograph_Digitization_Standard.pdf 